\title{
First record of Acanthocheilonema dracunculoides from domestic dogs in Namibia
}

\author{
E V Schwan ${ }^{\mathrm{a}^{*}}$ and F G Schröter ${ }^{\mathrm{b}}$
}

\begin{abstract}
Acanthocheilonema dracunculoides was diagnosed in 2 dogs from Windhoek, Namibia, by acid phosphatase staining of microfilariae. This is the 1 st record of $A$. dracunculoides in Namibia.

Key words: acid phosphatase staining, Acanthocheilonema dracunculoides, dog, microfilariae, Namibia.

Schwan E V, Schröter F G First record of Acanthocheilonema dracunculoides from domestic dogs in Namibia. Journal of the South African Veterinary Association (2006) 77(4): 220-221 (En.). Department of Veterinary Tropical Diseases, Faculty of Veterinary Science, University of Pretoria, Private Bag X04, Onderstepoort, 0110 South Africa.
\end{abstract}

Acanthocheilonema dracunculoides Cobbold, 1870 (syn. Dipetalonema dracunculoides), is a vector-borne nematode parasite (Filarioidea: Onchocercidae) of the domestic dog and some sylvatic carnivores (Proteles cristatus, aardwolf; Crocuta crocuta, spotted hyaena; Vulpes vulpes, red fox). The parasite occurs in Europe, Asia and Africa $^{28}$. In Africa it is known to be endemic in Morocco $^{20}$, Algeria $^{24}$, Tunisia ${ }^{4,27}$, Mali $^{14,22}$, Niger ${ }^{21}$, Democratic Republic of Congo $^{9}$, Sudan ${ }^{2}$, Somalia ${ }^{12}$, Kenya ${ }^{15,16}$, Tanzania $^{26}$ and South Africa ${ }^{7}$, in which country it was first described by Cobbold from an aardwolf. Acanthocheilonema dracunculoides follows an indirect life cycle. In those carnivores, which act as final hosts, the predilection site of the male and female adult parasites is mainly the peritoneal cavity ${ }^{19}$. Infection is often discovered accidentally during intraabdominal surgical procedures. Males are $15-32 \mathrm{~mm}$ long and $0.1-0.2 \mathrm{~mm}$ wide, whereas females are $30-60 \mathrm{~mm}$ long and $0.1-0.3 \mathrm{~mm}$ wide w $^{8,10,11,19,23}$. The male spicules are unequal and measure 273414 and $120-165 \mu \mathrm{m}$ in length respectively ${ }^{6,10,11,28}$. Sexually mature females are viviparous, i.e. they produce L1-stages, known as microfilariae, which eventually appear in the peripheral blood. Microfilariae are unsheathed and measure $185-276 \mu \mathrm{m}$ (length) by $4.2-6 \mu \mathrm{m}$ (width) $6,8,10,11,13,19,23,28$. So far, the louse fly Hippobosca longipennis and the hard

aDepartment of Veterinary Tropical Diseases, Faculty of Veterinary Science, University of Pretoria, Private Bag X04, Onderstepoort, 0110 South Africa.

${ }^{b}$ Formerly Windhoek Veterinary Clinic-Tierklinik, PO Box 5030, Windhoek, Namibia

Author for correspondence.

E-mail: vschwan@op.up.ac.za

Received: October 2005. Accepted: October 2006. tick Rhipicephalus sanguineus have been identified as intermediate hosts ${ }^{15,17}$. Microfilariae ingested during blood feeding transform into metacyclic (infective) L3-stages and eventually accumulate in the mouthparts of the respective arthropods involved. Final hosts become infected during blood feeding. The migrational pattern and development within the final hosts are unknown. Similarly, the duration of the prepatent and patent periods is unknown. Acanthocheilonema dracunculoides is regarded as largely apathogenic. However, there are several reports from Spain, where high prevalence rates of $A$. dracunculoides have been recorded, according to which infected dogs occasionally present with dermal clinical signs and lesions ranging from pruritus, alopecia, erythema to skin ulcers as well as other clinical signs such as ataxy, incoordination, cachexia and pleural effusion ${ }^{5,19,25}$. From a differential diagnostic point of view, A. dracunculoides must always be considered in connection with canine filarioses of other aetiologies and in particular cardiovascular dirofilariosis caused by Dirofilaria immitis, colloquially known as heartworm. This paper represents the 1st record of $A$. dracunculoides in Namibia. The parasite was encountered in 2 domestic dogs.

An 8-year-old St. Bernard bitch (Dog A) and a crossbred male dog of unknown age (Dog B) of different ownership were presented to the Windhoek Veterinary Clinic in Windhoek, Namibia, with inappetence and poor appetite. Physical examination of Dog A revealed a slightly elevated rectal temperature of $39.6{ }^{\circ} \mathrm{C}$, marked weight loss, inappetance and ascites. Cardiomegaly and hepatomegaly were diagnosed on radiographic examination. Physical examination of Dog B additionally revealed vomiting, hind leg lameness and a bilateral corneal oedema. Cam's Quick-stained thin blood films prepared from peripheral blood obtained from a pricked ear pinna of both animals revealed the presence of isolated microfilariae as well as a marked leukocytosis and eosinophilia. Additional blood samples were collected from the cephalic vein of both animals into EDTA coated vacuum tubes to conduct further analysis of microfilariae. Of each sample, a $2 \mathrm{~m} l$ aliquot was screened for microfilariae by membrane filtration using $3.0 \mu \mathrm{m}$ Isopore $^{\circledR}$ membrane filters (Millipore) stained with Giemsa ${ }^{3}$. Examination of the Giemsa-stained membrane filters showed the presence of unsheathed microfilariae. They varied in width from $4.7 \mu \mathrm{m}$ to $5.6 \mu \mathrm{m}$ at the widest part of the anterior end and varied in length from 218 to $243 \mu \mathrm{m}$. The microfilariae were eventually identified by acid phosphatase staining as those of Acanthocheilonema dracunculoides, showing the typical somatic pattern of enzyme activity at the cephalic vesicle, excretory pore, 'Innenkörper' (inner body) and anal pore ${ }^{6,18,29}$ (Fig. 1). The animals were treated with ivermectin (Ivomec Injection, Merial) at $200 \mu \mathrm{g} / \mathrm{kg}$ once subcutaneously but could not be followed up. Both animals had never left Namibian territory.

Acanthocheilonema dracunculoides has never before been reported from the domestic dog or any sylvatic carnivore in Namibia. Although the species is regarded as largely apathogenic in dogs, there is some evidence reported from Spain that suggests that occasionally the parasite may not be as innocuous as generally assumed $^{5,19,25}$. Dermal clinical signs interpreted as a result of $A$. dracunculoides infection improved following treatment with ivermectin at a dose rate of $50 \mu \mathrm{g} / \mathrm{kg}$ administered subcutaneously or per os ${ }^{25}$. Whether the clinical signs or part of them recorded in Dog A and Dog B are a sequel of the filarial infection diagnosed, cannot be answered considering the scarce clinical information available and the fact that the animals were not followed up. 


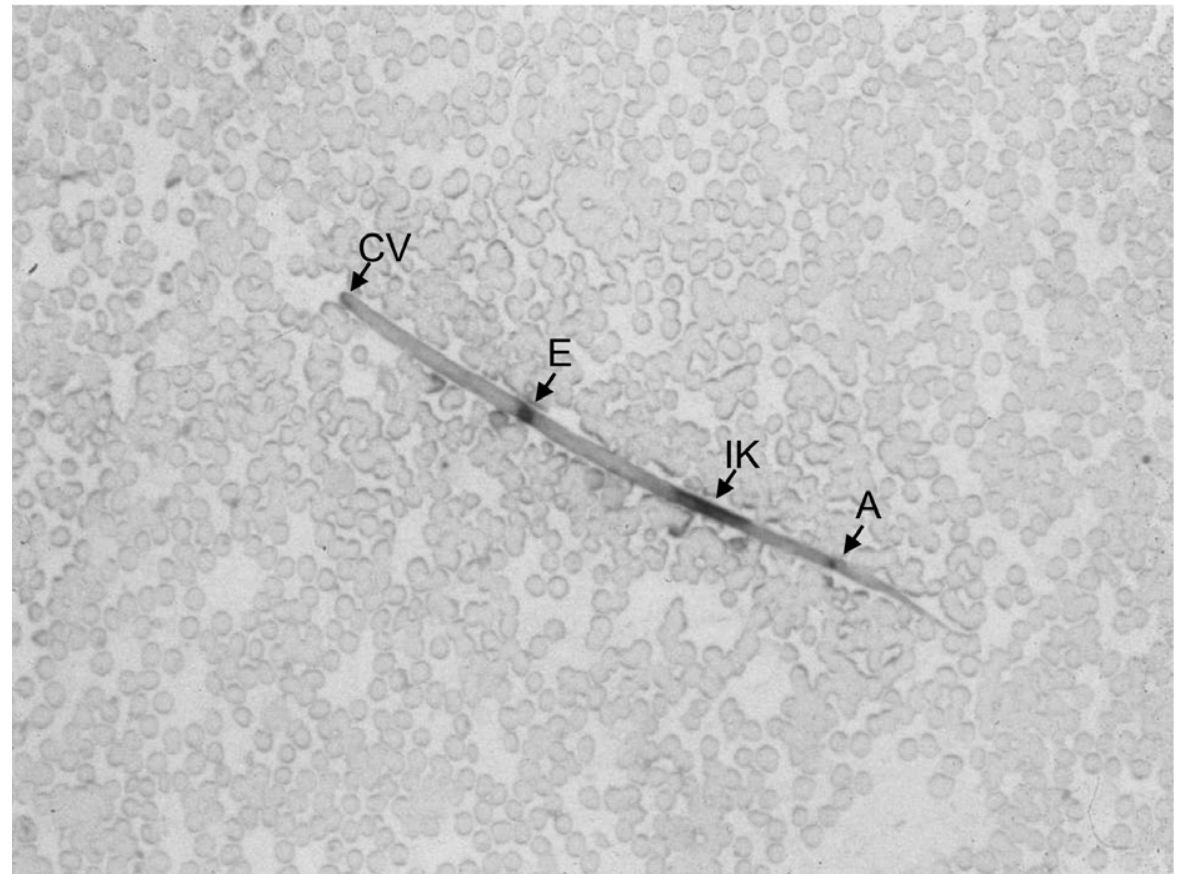

Fig. 1: Acanthocheilonema dracunculoides microfilaria showing acid phosphatase activity at the cephalic vesicle (CV), excretory pore (E), 'Innenkörper' (IK) and anal pore (A).

\section{ACKNOWLEDGEMENTS}

The senior author would like to acknowledge Mrs A. Lourens from the library of the Faculty of Veterinary Science for her relentless effort in obtaining articles from overseas.

\section{REFERENCES}

1. Balbo T, Abate O 1972 Histochemical differentiation of microfilariae of Dirofilaria immitis, Dirofilaria repens and Dipetalonema sp. Parassitologia 14: 239-244

2. Baylis H A 1929 A manual of helminthology medical and veterinary. Baillière, Tindall and Cox, London

3. Bell D 1967 Membrane filters and microfilariae: a new technique. Annals of Tropical Medicine and Parasitology 61: 220-223

4. Bernard J, Ben Osman F, Juminer B 1967 Enquête sur les helminthes parasites du chien (Canis familiaris L.) à Tunis-ville. Archives de l'Institute Pasteur de Tunis 44: 1-89

5. Bolio ME, Montes A M, Gutierrez C, Alonso F D, Bernal L J, Sauri C H, RodríguezVivas R I 2002 Hallazgos clínicos en perros parasitados por Dipetalonema dracunculoides. Archivos de medicina veterinaria 34: 283-286

6. Chauve C M 1990 Dirofilaria repens (Railliet et Henry, 1911), Dipetalonema reconditum (Grassi, 1890), Dipetalonema dracunculoides (Cobbold, 1870) et Dipetalonema grassii (Noé, 1907): quatre filaires méconnues du chien. Pratique Médicale et Chirurgicale de l'Animal de Compagnie 25: 293-304

7. Cobbold T S 1870 Description of a new
Helminthology 37: 235-240

16. Nelson G S, Heisch R B, Furlong M 1962 Studies in filariasis in East Africa II. Filarial infections in man, animals and mosquitoes on the Kenya coast. Transactions of the Royal Society of Tropical Medicine and Hygiene 56: 202-217

17. Olmeda-García A S, Rodríguez-Rodríguez J A, Rojo-Vázquez F A 1993 Experimental transmission of Dipetalonema dracunculoides (Cobbold 1870) by Rhipicephalus sanguineus (Latreille 1806). Veterinary Parasitology 47: 339-342

18. Ortega-Mora L M, Gomez-Bautista M, Rojo-Vázquez F A 1989 The acid phosphatase activity and morphological characteristics of Dipetalonema dracunculoides (Cobbold, 1870) microfilariae. Veterinary Parasitology 33: 187-190

19. Ortega-Mora L M, Rojo-Vázquez F A 1988 Sobre la presencia de Dipetalonema dracunculoides (Cobbold, 1870) en el perro en España. Revista Ibérica de Parasitología 48: 187-188

20. Pandey V S, Dakkak A, Elmamoune M 1987 Parasites of stray dogs in the Rabat region, Morocco. Annals of Tropical Medicine and Parasitology 81: 53-55

21. Railliet A, Henry A 1911 Filaire à embryons sanguicoles de l'Hyaena crocuta Erxleben [Discussion]. Bulletin de la Société de Pathologie Exotique 5: 630-631

22. Railliet A, Henry A, Langeron M 1912 Le genre Acanthocheilonema Cobbold, et les filaires péritonéales des carnivores. Bulletin de la Société de Pathologie Exotique 5: 392-395

23. Rao MAN 1938 Dipetalonema dracunculoides (Cobbold, 1870). The Indian Journal of Veterinary Science and Animal Husbandry 8: 127130

24. Rioche M 1960 Présence de Dipetalonema dracunculoides (Cobbold, 1870) chez le chien dans la Région d'Algier. Archives de l'Institut Pasteur d'Algerie 38: 386-398

25. Rodríguez J F 1990 Dirofilariasis canina y otras parasitosis filariales. Incidencia, diagnóstico, tratamiento y prevención. Pequeños Animales 2: 91-111

26. Sachs R 1976 Filarien in Körperhöhlen, subkutanem Bindegewebe und anderen Organsystemen bei Wildherbivoren in Ostafrika. In Ippen R, Schröder H D (eds), Erkrankungen der Zootiere. Verhandlungsbericht des XVIII Internationalen Symposiums über die Erkrankungen der Zootiere, Innsbruck, Österreich, 16-20 June 1976: 195-203

27. Seurat L G 1918 Contribution a l'étude de la faune parasitaire de la Tunisie. Nématodes. Archives de l'Institut Pasteur de Tunis 10: 243-275

28. Sonin M D 1975 Filariata of animals and man and diseases caused by them. Part III. Filariidae, Onchocercinae. Amerind Publishing, New Delhi

29. Valcárcel F, Ferre I, Gómez-Bautista M, Rojo-Vázquez F A 1990 Diagnóstico de laboratorio de la infestación por Dirofilaria immitis en el perro. Medicina Veterinaria 7: 345-353 